\title{
Implementasi Penyuluhan Hortikultura Berkelanjutan di Provinsi D.I. Yogyakarta
}

\section{The Implementation of Sustainable Horticulture Extension in the Special Region of Yogyakarta}

\author{
Epsi Euriga $^{1}$, Siti Amanah ${ }^{2}$, Anna Fatchiya ${ }^{2}$, Pang S. Asngari² \\ ${ }^{1}$ Sekolah Tinggi Penyuluhan Pertanian, Kementerian Pertanian \\ ${ }^{2}$ Departemen Sains Komunikasi dan Pengembangan Masyarakat, Fakultas Ekologi Manusia, Institut Pertanian Bogor
}

\begin{abstract}
In accordance with the Law No. 16 of 2006 on Agricultural Extension System, Fishery and Forestry, the implementation of agricultural extension commenced an emphasis on the aspect of sustainability such as raising awareness in the preservation of environmental meanings. Sustainable horticulture is one of the innovations in implementing agriculture without damaging the environment. Adoption of sustainable horticulture has not been fully implemented by horticultural farmers in Special Region of Yogyakarta (DIY) even though the government has already implemented the extension. The previous research mentioned that one of the factors influencing an adoption is extension services. This study aims to analyze the effectivity of the implementation of sustainable horticultural extension in DIY. The population of horticulture farmer group was 2621 farmers from 209 groups. The sampling method was done by multi stage random sampling. This study involved 350 horticultural farmers as respondents in Sleman, Kulonprogo, and Bantul by using Slovin formula for the representation of the population. Data collected using interview and analyzed using descriptive statistics SPSS. The survey results show that the effectivity of the extension in DIY is in the high category: extension materials, extension methods and extension competence were in the high category, while the participation of farmers is in the medium category. The extension materials therefore need to be strengthened concerning mulch and marketing by considering the environmental and economic feasibility aspects. Extension methods must be improved by training and field schools. Extension workers competence in driving farmers to reduce the use of chemicals in eradicating pests and weeds needs to be improved. Extension workers should increase the frequency of meetings with the farmers to increase farmers 'participation.
\end{abstract}

Keywords: competency, extension, material, method, participation, sustainable horticulture

\begin{abstract}
Abstrak
Sesuai amanah Undang-Undang No.16 Tahun 2006 tentang Sistem Penyuluhan Pertanian, Perikanan dan Kehutanan, implementasi penyuluhan mulai memfokuskan pada aspek keberlanjutan yaitu meningkatkan kesadaran dalam pelestarian fungsi lingkungan hidup. Hortikultura berkelanjutan merupakan salah satu inovasi dalam melaksanakan pertanian tanpa merusak lingkungan. Adopsi hortikultura berkelanjutan belum sepenuhnya dilaksanakan oleh petani hortikultura di Provinsi Daerah Istimewa Yogyakarta (DIY) meskipun telah dilaksanakan penyuluhan. Penelitian sebelumnya menyebutkan bahwa salah satu faktor yang memengaruhi suatu adopsi adalah penyuluhan. Penelitian ini bertujuan untuk menganalisis efektivitas implementasi penyuluhan hortikultura berkelanjutan di Provinsi DIY. Populasi kelompok tani Hortikultura berjumlah 209 kelompok dengan total anggota 2621 petani. Metode pengambilan sampel dilakukan secara probability sampling acak bertingkat. Penentuan jumlah sampel dengan menggunakan rumus Slovin untuk keterwakilan populasi dengan taraf signifikansi $\alpha=0,05$ sehingga diperoleh 350 petani hortikultura sebagai responden di Kabupaten Sleman, Kulonprogo dan Bantul. Analisis data menggunakan statistik deskriptif menggunakan SPSS. Hasil survey menunjukkan bahwa efektivitas implementasi penyuluhan di DIY berada dalam kategori tinggi, yaitu: materi penyuluhan, metode penyuluhan dan kompetensi penyuluh pada kategori tinggi, sedangkan keterlibatan petani pada kategori sedang. Materi penyuluhan perlu diperkuat dalam hal penggunaan mulsa dan pemasaran dengan mempertimbangkan aspek kelayakan lingkungan dan ekonomi. Metode penyuluhan ditingkatkan dengan pelatihan dan sekolah lapang. Penyuluh harus meningkatkan kompetensi untuk mengajak petani agar mengurangi penggunaan bahan kimia dalam memberantas hama dan gulma. Untuk meningkatkan partisipasi petani penyuluh harus meningkatkan frekuensi pertemuan dengan petani.
\end{abstract}

Kata kunci: hortikultura berkelanjutan, materi, metode, kompetensi, partisipasi, penyuluhan

\section{Pendahuluan}

Petani adalah satu kelompok terbesar yang merupakan pengguna dan pengelola tanah, air dan sumber daya alam. Demikian halnya di Provinsi Daerah Istimewa Yogyakarta (DIY), tercermin dari penduduk yang

\footnotetext{
${ }^{1}$ Korespondensi penulis

E-mail: epsieuriga@gmail.com
} 
sebagian besar adalah petani. Mayoritas petani memerlukan informasi yang berguna, teknologi yang sesuai dan bimbingan teknis yang penting untuk meningkatkan tidak hanya produktivitas dan pendapatan namun juga agar kehidupan pertanian dan pedesaan semakin kaya dan berkelanjutan. Hal ini menjadi peran penting dalam penyuluhan pertanian agar memberikan materi yang sesuai dengan harapan petani tersebut.

Swanson et al. (1997) menjelaskan bahwa integrasi antara makanan, populasi dan lingkungan telah mendorong pengembangan seperti yang dilakukan FAO dan disebut sebagai sustainable agricultural and rural development (SARD). Konsep SARD didefinisikan FAO sebagai pengelolaan dan konservasi sumber daya alam dan berorientasi pada perubahan teknologi dan kelembagaan dengan aturan tertentu untuk memastikan pencapaian dan kepuasan yang berkelanjutan bagi kebutuhan manusia saat ini dan generasi mendatang. Pengembangan berkelanjutan (dalam sektor pertanian, kehutanan dan perikanan) mengkonservasi tanah, air, tanaman dan sumber genetik binatang ini tidak mendegradasi lingkungan, sesuai secara teknologi, layak secara ekonomi dan diterima secara sosial (FAO 1991). Peran petani untuk mengorganisasikan SARD dalam hal pengelolaan dan konservasi tanah, air, dan sumber daya biologi, memelihara keseimbangan ekologi dan menerapkan teknologi ramah lingkungan seperti pengelolaan hama terpadu (PHT).

Definisi penyuluhan dalam Undang-Undang No.16 Tahun 2006 tentang Sistem Penyuluhan Pertanian, Perikanan dan Kehutanan menyiratkan pentingnya penyuluhan mengenai pertanian berkelanjutan. Dalam undang-undang tersebut penyuluhan didefinisikan sebagai proses pembelajaran bagi pelaku utama serta pelaku usaha agar mereka mau dan mampu menolong dan mengorganisasikan dirinya dalam mengakses informasi pasar, teknologi, permodalan, dan sumber daya lainnya, sebagai upaya untuk meningkatkan produktivitas, efektivitas usaha, pendapatan, dan kesejahteraannya, serta meningkatkan kesadaran dalam pelestarian fungsi lingkungan hidup.

Pertanian berkelanjutan merupakan pendekatan pemenuhan pangan bagi manusia tanpa merusak alam dengan input yang rendah (Thanha dan Yapwattanaphun 2015). Pertanian berkelanjutan mensyaratkan lingkungan harus tetap dipertahankan kelestariannya karena akan berdampak pada kesejahteraan petani di masa mendatang.
Data BPS DIY (2014) menunjukkan bahwa kemiskinan terjadi pada desa yang memiliki mata pencaharian mayoritas sebagai petani. Data BPS tersebut juga menunjukkan adanya ketidakstabilan produktivitas hortikultura. Sesuai fakta dan undang-undang yang ada, implementasi penyuluhan mengenai pertanian berkelanjutan dalam bidang hortikultura atau dapat disebut hortikultura berkelanjutan perlu dilaksanakan.

Program penyuluhan pemerintah yang mencakup beberapa aspek pertanian berkelanjutan telah banyak dilakukan seperti Sekolah Lapang Iklim (SLI), Sekolah Lapang-Pengelolaan Tanaman Terpadu (SL-PTT), Sekolah Lapang -Pengendalian Hama Terpadu (SLPHT), General Agricultural Practices-Standard Operating Procedure (GAP-SOP) dan model Akselerasi Pembangunan Pertanian Ramah Lingkungan Lestari (m-AP2RL2). Program-program penyuluhan tersebut ternyata belum sepenuhnya efektif dalam mendorong petani untuk menerapkan hortikultura berkelanjutan.

Penelitian terdahulu menunjukkan bahwa dukungan penyuluhan merupakan salah satu faktor yang menentukan keberhasilan penerapan suatu adopsi inovasi (Jamal et al. 2014 danAbdollahzadeh et al. 2015). Hortikultura berkelanjutan dapat dikatakan sebagai suatu inovasi. Keberhasilan penyuluhan sangat bergantung pada materi, metode dan SDM agen penyuluhan dan juga keterlibatan petani. Materi penyuluhan harus memenuhi aspek hortikultura berkelanjutan dan juga kelayakan teknis, kelayakan ekonomi, penerimaan sosial serta keamanan bagi lingkungan (Swanson et al. 1997).

Proses penyuluhan dapat dilihat dari metode penyuluhan yang dipilih berupa jumlah kunjungan, pertemuan lapang, pertemuan kelompok, demonstrasi, studi banding atau pertukaran petani dan pelatihan petani (Swanson et al. 1997). Semakin beragam dan semakin sering maka proses penyuluhan dapat dikatakan berkualitas. Bukti di lapangan juga menunjukkan bahwa kelompok tani hortikultura yang sering terlibat dalam kegiatan penyuluhan terutama di Kota Yogyakarta tergolong dalam kelompok yang memiliki kelas lanjut dan utama.

Selain metode penyuluhan, dari segi sumber daya manusia, kinerja dan tingkat pentingnya kompetensi penyuluh profesional perlu diukur cara penyuluh membuat material pendidikan/pembelajaran, penggunaan audio-visual, metode demonstrasi, menilai kebutuhan 
masyarakat, menentukan informasi yang dibutuhkan untuk evaluasi dan menentukan anggaran program penyuluhan (Swanson et al. 1997).

Penyuluhan yang berhasil juga memerlukan partisipasi atau keterlibatan petani karena akan memengaruhi adopsi inovasi sebagaimana pendapat Kassie et al. (2013), Okuthe (2014), Timprasert et al. (2014) dan Pretty (1995a).

Berdasarkan latar belakang tersebut, maka penelitian ini bertujuan untuk menganalisis tingkat efektivitas implementasi penyuluhan hortikultura berkelanjutan pada petani hortikultura di DIY.

\section{Metode Penelitian}

Penelitian dilakukan pada tahun 2016 di tiga kabupaten yang berada di Provinsi DIY yaitu Kabupaten Sleman, Kulonprogo dan Bantul. Populasi penelitian ini adalah seluruh anggota kelompok tani Hortikultura yang berada di Provinsi Daerah Istimewa Yogyakarta yang berjumlah 209 kelompok dengan total anggota 2621 petani. Metode pengambilan sampel dilakukan secara probability sampling acak bertingkat yaitu multi stage random sampling. Penentuan jumlah sampel dengan menggunakan rumus Slovin untuk keterwakilan populasi dengan taraf signifikansi $\alpha=0,05$ sehingga diperoleh Total responden 347 (dibulatkan 350 petani hortikultura).

Jika setiap kelompok diambil 5 responden, diperlukan sampel sebanyak 70 kelompok. Dari data di Provinsi DIY, kelompok wanita tani (KWT) hortikultura berjumlah 39 kelompok (19 persen) dan kelompok tani sebanyak 170 kelompok (81 persen) dari 209 kelompok. Sesuai dengan proporsi tersebut maka diambil sampel sebanyak 13 kelompok wanita tani hortikultura dan 57 kelompok tani hortikultura.

Data primer diperoleh dengan menggunakan kuisioner yang disusun berdasarkan tujuan penelitian berupa pernyataan dengan skala likert (tidak pernah $=1$, jarang $=2$, sering $=3$, selalu $=4$ ), pertanyaan terbuka dan tertutup. Skala likert kemudin dikategorikan menjadi tiga bagian sesuai kuartil atau mean dan standar deviasi skor jawaban responden dan kemudian interpretasi skor keseluruhan dihasilkan dari pembobotan jawaban seluruh responden dengan kategori tinggi (2-3), sedang

\section{(1.1-1.99) dan rendah (0-1).}

Pernyataan dan pertanyaan diidentifikasi dari berbagai penelitian terdahulu masing-masing variabel. Variabel yang diukur meliputi: efektivitas implementasi penyuluhan, faktor internal dan persepsi petani mengenai hortikultura berkelanjutan. Data yang terkumpul kemudian dianalisis menggunakan analisis statitiska deskriptif menggunakan SPSS.

\section{Hasil dan Pembahasan}

\section{Implementasi Penyuluhan di DIY}

Konsentrasi kelompok tani hortikultura di DIY terbanyak berada di Kabupaten Sleman dengan Salak sebagai komoditas utama. Komoditas utama di Bantul adalah bawang merah, sedangkan di Kulonprogo bervariasi dari cabai, semangka dan melon. Lokasi lahan di Sleman rata-rata berada di wilayah pegunungan, sedangkan lokasi lahan di Bantul dan Kulonprogo berada di sekitar pantai. Karakteristik topografi tersebut mengarahkan petani untuk menanam komoditas yang sesuai dengan kondisi alam.

Berdasarkan jenis kelompok, kelompok tani tanaman pangan memiliki jumlah yang paling banyak dibandingkan dengan kelompok tani lainnya (Tabel 2). Sedangkan kelompok tani hortikultura memiliki jumlah paling rendah. Implementasi penyuluhan pada petani hortikultura dilaksanakan oleh berbagai pihak melalui Balai Penyuluhan Pertanian, Perikanan dan Kehutanan (BP3K) yang berjumlah 56 BP3K. Rasio satu desa satu penyuluh belum terpenuhi, kekurangan penyuluh PNS masih terjadi di DIY, yaitu 296 penyuluh pegawai negeri sipil untuk 392 desa. Kekurangan penyuluh tersebut masih terbantu dengan adanya 240 penyuluh tenaga harian lepas, dan 246 penyuluh swadaya.

Survei lapangan menunjukkan bahwa dari 350 responden, 152 responden belum pernah mengikuti pelatihan non-formal. Tabel 3 menunjukkan jenis pelatihanyang diikuti selamamenjadi anggotakelompok, satu responden kadang mengikuti pelatihan lebih dari satu jenis. Pelatihan lebih sering diikuti oleh pengurus dengan harapan hasil pelatihan akan disebarluaskan oleh pengurus kepada anggota dan petani lainnya.

Tabel 4 menunjukkan distribusi jawaban responden 
mengenai efektivitas implementasi penyuluhan di DIY. Jika dilihat dari target yang diharapkan dalam skala 1-100 persen maka efektivitas implementasi penyuluhan di Yogyakarta mencapai 76 persen, dengan presentase masing-masing; materi penyuluhan (68 persen), metode penyuluhan (82 persen), kompetensi penyuluh (90 persen) dan keterlibatan petani (66 persen).

Hasil analisis menunjukkan bahwa efektivitas implementasi penyuluhan diDIY berada dalam kategori tinggi (skor likert $=2.28$ ) dengan materi penyuluhan, metode penyuluhan dan kompetensi penyuluh pada kategori tinggi, sedangkan keterlibatan petani pada kategori sedang (Gambar 1). Gambar 2 menunjukkan bahwa implementasi penyuluhan terbaik dari seluruh aspek adalah Kabupaten Kulonprogo. Implementasi penyuluhanmasih memiliki potensi perbaikan dari segi keterlibatan petani dan konten penyuluhan.

\section{Kesesuaian Materi atau Konten Penyuluhan}

Penelitian ini mendefinisikan kesesuaian materi adalah relevansi isi informasi dan teknologi yang disampaikan oleh penyuluh yaitu telah mencakup aspek hortikultura berkelanjutan dan juga memenuhi kelayakan teknologi, kelayakan ekonomi, penerimaan sosial dan keamanan lingkungan.

Materi penyuluhan hortikultura berkelanjutan di DIY yang disampaikan penyuluh berada dalam kategori tinggi (skor likert $=2.02$ ). Skor tersebut hampir mendekati kategori sedang karena materi yang disampaikan belum sepenuhnya mencakup seluruh aspek HB dan lebih menekankan kepada swasembada dibanding HB.

Secara rinci, penerimaan materi hortikultura berkelanjutan melalui penyuluhan diuraikan dalam Gambar 3. Materi yang paling sering diterima adalah pengairan sesuai kebutuhan tanaman, diikuti dengan penggunaan pupuk organik/kompos dan penggunaan alat pelindung tubuh dalam bertani. Sedangkan materi yang paling jarang diterima adalah menutup tanah dengan jerami / bahan organik sebagai mulsa, pemasaran, rotasi (penggiliran tanaman) dan kemitraan/ kerja sama (baik input/budi daya/pemasaran) sehingga penyuluh perlu meningkatkan frekuensi penyuluhan pada materi tersebut.

Dari fakta di lapangan memang petani jarang menerapkan mulsa terutama petani salak karena dianggap tidak perlu, namun ada beberapa petani yang menerapkan pada lahan dengan memanfaatkan sisa-sisa pemangkasan pohon salak. Materi terkait pemasaran yang jarang dilakukan mengakibatkan petani sering kesulitan memasarkan hasil panen meskipun produktivitas tinggi bahkan beberapa petani yang menerapkan pertanian organik mendapatkan harga yang sama dengan petani konvensional. Penelitian terdahulu menyebutkan bahwa kapasitas petani dalam agribisnis padi organik pada pemasaran lebih dipengaruhi oleh dinamika kelompok yaitu dengan adanya kejelasan tujuan kelompok, berjalannya fungsi kontrol kelompok, dan suasana yang kondusif. Peran penyuluh sangat diperlukan untuk mendorong

Tabel 2. Rekap Kelompok Tani berdasarkan Jenis Kelompok Provinsi Daerah Istimewa Yogyakarta

\begin{tabular}{llcccccccc}
\hline No & Kabupaten & $\begin{array}{c}\text { Jumlah } \\
\text { Poktan }\end{array}$ & Domisili & Perempuan & $\begin{array}{c}\text { Jenis Kelompok Tani } \\
\text { Pangan }\end{array}$ & Horti & $\begin{array}{c}\text { Per- } \\
\text { kebunan }\end{array}$ & Peternakan & Belum \\
Diketahui
\end{tabular}

Sumber: Pusat Penyuluhan Pertanian, BPPSDMP, Kementerian Pertanian 2015 
Tabel 3. Jenis-Jenis Pelatihan yang Pernah Diikuti oleh Responden

\begin{tabular}{lcr}
\hline & Frekuensi & \multicolumn{1}{c}{$\%$} \\
\hline $\begin{array}{l}\text { Sekolah Lapang - Pengendalian } \\
\text { Hama Terpadu (SLPHT) }\end{array}$ & 84 & 32,94 \\
Sekolah Lapang - Good & & \\
Agricultural Practices (SL-GAP) & 45 & 17,65 \\
Sekolah Lapang - Good Handling & & \\
Practices salak pondoh (SLGHP) & 32 & 12,55 \\
Pelatihan Organik & 21 & 8,24 \\
Pelatihan Budidaya & 24 & 9,41 \\
Pelatihan Pengolahan/Pasca & 13 & 5,10 \\
Panen & & \\
Sekolah Lapang Pengelolaan & 12 & 4,71 \\
Tanaman Terpadu (SLPTT) & 12 & 4,71 \\
Pelatihan Manajemen & 9 & 3,53 \\
Pelatihan Pemasaran & 3 & 1,18 \\
Sekolah Lapang - Iklim (SLI) & 255 & 100 \\
Total & & \\
\hline
\end{tabular}

kebersamaan kelompok (organisator). Rotasi tanaman jarang dilakukan pada petani salak karena sifatnya merupakan tanaman jangka Panjang, namun sering dilakukan pada petani cabai, melon, bawang merah. Swanson et al. 1997 mengungkapkan bahwa kesesuaian materi bergantung pada situasi, misalnya kesesuaian untuk satu keluarga belum tentu sesuai untuk yang lainnya meskipun berada dalam zona agroekologi yang sama atau sesuai untuk satu negara belum tentu sesuai untuk negara lain. Hayami and Ruttan (1985) menunjukkan bahwa di Jepang, ketika tanah merupakan sesuatu yang langka, pengembangan teknologi diorientasikan pada teknologi biologi seperti perbaikan varietas. Berbeda dengan Amerika Serikat yang memiliki tanah berlimpah, teknologi yang dikembangkan adalah dalam bentuk inovasi mekanis seperti traktor. Negara berkembang lebih mengutamakan komersialisasi teknologi sesuai permintaan pasar tanpa memperhatikan kesesuaian dengan para petaninya.

Kemitraan atau kerjasama justru lebih banyak diperoleh petani dari aktivitas asosiasi petani. Meskipun penyuluhan juga membuka jalan bagi petani untuk kemitraan dengan berbagai pihak misalnya dari pihak asing untuk sertifikasi lahan organik. Materi pemasaran produk memang masih minim diberikan kepada petani melalui penyuluhan. Beberapa petani mengeluh mereka berhasil melaksanakan pertanian organik tetapi terkendala dengan pemasaran, pada akhirnya beberapa petani menjual produknya dengan harga yang sama dengan produk hasil panen pertanian konvensional.

Pengemasan hasil panen kebanyakan dilakukan pada penyuluhan yang melibatkan kelompok wanita tani (KWT) saja sedangkan pada kelompok tani cenderung mencari informasi sendiri melalui teman sesama petani ataupun dari asosiasi petani. Sebagai contoh seorang petani mempelajari cara membuat kemasan untuk menampung salak dengan kualitas ekspor. Mereka kesulitan mendapatkan kemasan tersebut sehingga membuat sendiri kemasan salak dengan meniru kemasan yang sudah ada. Kemasan ini didapatkan dari petani lain yang melakukan eskpor salak.

Berdasarkan argumen tersebut maka kesesuaian yang dipersepsikan petani didefinisikan dalam lingkup yaitu: (1) kelayakan teknis (teknis dapat dilaksanakan), (2) kelayakan ekonomi (ekonomis menguntungkan), (3) penerimaan sosial (sesuai dengan norma atau nilainilai masyarakat) dan (4) aman bagi lingkungan dan berkelanjutan (sesuai dengan kebijakan pemerintah).

Gambar 4 menunjukkan alasan petani melaksanakan materi penyuluhan yang diberikan selama selama dua tahun terakhir. Alasan tertinggi adalah untuk mempertahankan keanekaragaman hayati dan menguntungkan, sedangkan alasan terendah adalah

Tabel 4 Distribusi kualitas penyelenggaraan penyuluhan di DIY

\begin{tabular}{lccccccc}
\hline \multicolumn{1}{c}{ Komponen } & $\begin{array}{c}\text { Tinggi } \\
(\mathrm{n})\end{array}$ & $\%$ & $\begin{array}{c}\text { Sedang } \\
(\mathrm{n})\end{array}$ & $\%$ & $\begin{array}{c}\text { Rendah } \\
(\mathrm{n})\end{array}$ & $\%$ & $\begin{array}{c}\text { Skor total } \\
(\%)\end{array}$ \\
\hline Materi penyuluhan & 65 & 18.6 & 229 & 65.4 & 56 & 16 & 68 \\
Metode penyuluhan & 60 & 17.1 & 219 & 62.6 & 71 & 20.3 & 82 \\
Kompetensi penyuluh & 39 & 11.2 & 278 & 79.4 & 33 & 9.4 & 90 \\
Keterlibatan petani & 39 & 11.2 & 263 & 75.1 & 48 & 13.7 & 66 \\
\hline
\end{tabular}




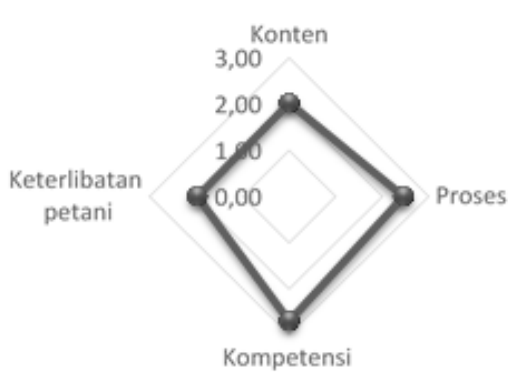

Gambar 1 Distribusi skor likert penyuluhan di DIY

harga jual yang tinggi serta bahan-bahan untuk menerapkan mudah. Hal ini sejalan dengan penelitian Suryani (2017) yang menunjukkan bahwa petani akan melanjutkan adopsi berdasarkan keuntungan relatif dan kesesuaian inovasi. Hasil ini juga menunjukkan bahwa petani mempertimbangkan secara seimbang antara lingkungan dan ekonomi, atau dengan kata lain petani ingin memperoleh keuntungan namun tetap mengutamakan kelestarian lingkungan.

\section{(1) Kelayakan Teknis}

Swanson et al. 1997 mengungkapkan bahwa kelayakan teknis harus diuji melalui dua perspektif yaitu pertama, petani mampu memproduksi komoditas dalam lingkungan mereka dan kedua berdasar apa yang dapat dicapai keluarga petani bukan berdasar apa yang dicapai lembaga riset. Dalam kasus pertama, komoditas tertentu tidak cocok dengan sistem produksi petani dan kasus kedua harus membedakan antara potensi

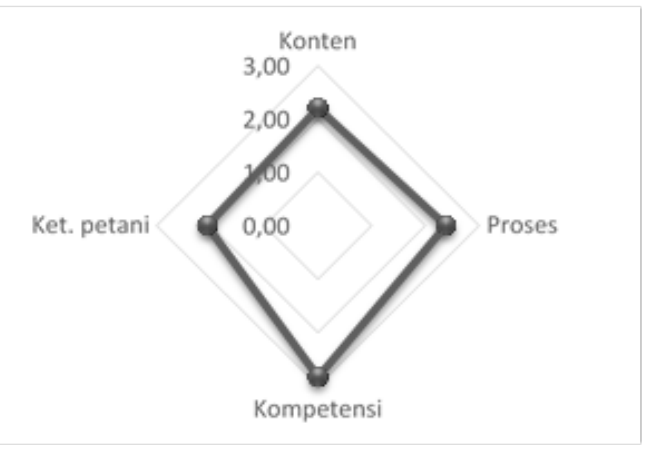

Gambar 2 Distribusi skor likert penyuluhan di Kulonprogo

teknologi dan kelayakan teknis. Potensi teknologi adalah output yang diuji berdasarkan teknologi tertentu dan didasarkan pada faktor agronomi. Kelayakan teknis adalah apa yang dapat dicapai oleh lingkungan keseluruhan keluarga petani tidak terbatas pada faktor teknis tetapi juga sosial, ekonomi dan politik yang memengaruhi keluarga petani. Petani kecil yang cenderung dalam kondisi tidak memuaskan biasanya berproduksi dibawah potensi teknologi. Sesuai dengan situasi ini apa yang penting bagi petani adalah komoditas dapat sesuai dengan sistem pertanian. Jika teknologinya sesuai maka layak secara teknologi.

Prioritas kelayakan teknis yang dipertimbangkan petani dalam implementasi materi penyuluhan hortikultura berkelanjutan secara berturut-turut adalah (1) mudah diterapkan, (2) waktu untuk menerapkan tersedia, (3) sesuai dengan lingkungan (cuaca, suhu, kelembaban dan lain-lain), (4) tenaga kerja untuk menerapkan tersedia, dan (5) alat dan bahan untuk menerapkan

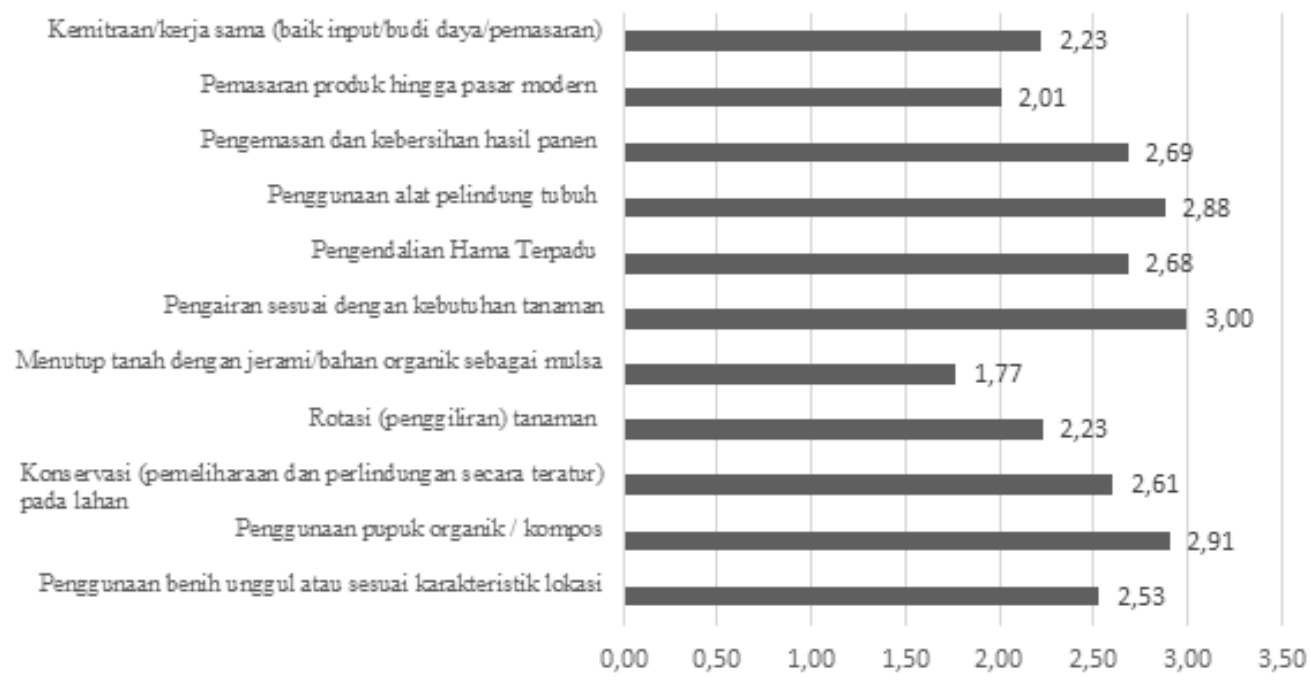

Gambar 3. Skor Likert Penerimaan Materi Penyuluhan Hortikultura Berkelanjutan 
tersedia.

\section{(2) Kelayakan ekonomi}

Swanson et al. 1997 mengungkapkan bahwa kemampuan petani untuk melaksanakan sebuah teknologi atau paket teknologi pada sistem pertanian dapat berimplikasi ekonomis. Petani memiliki sumber daya yang harus dipertimbangkan yaitu sumber daya manusia dan keuangan.

Apakah petani memiliki sumber daya keuangan untuk membeli input agar memperoleh keuntungan dari teknologi? Apakah teknologi mensyaratkan penambahan tenaga kerja? jika ya, apakah tersedia dan dapat dilakukan? Beberapa teknologi revolusi hijau gagal diadopsi karena beberapa pengguna tidak dapat membeli pupuk dan input lainnya yang dikemas dalam satu paket. Kelayakan ekonomi dapat pula diukur dengan pandangan sistem pertanian. Sebagai contoh adalah petani kecil pisang di Pulau Eindeard Timur Karibia tetap menanam pisang meskipun mereka disarankan untuk tidak menanam.

Rasionalisasi dari saran tersebut adalah erosi tanah pada kemiringan yang sangat curam dan sebagian besar petani menanam pisang yang tidak memberikan keuntungan bagi mereka. Meskipun demikian budi daya pisang memberikan mereka akses input sehingga mereka dapat meningkatkan keuntungan tanaman lain dalam sistem pertanian sehingga membuat sistem pertanian secara keseluruhan menguntungkan. Budi daya tanaman pisang dalam sebuah sistem ini disebut petani sebagai tanaman fasilitator yang tidak menguntungkan secara ekonomi.

(3) Sebanyak 93.14 persen petani menyatakan bahwa mereka akan melaksanakan materi penyuluhan hortikultura berkelanjutan apabila menguntungkan, 86.29 persen menyatakan akan melaksanakan apabila hasil panen meningkat. Untuk kelayakan ekonomi lainnya seperti biaya untuk menerapkan tersedia, hanya 70 persen petani yang akan melaksanakan, dan meskipun harga jual tinggi, hanya 60 persen petani akan
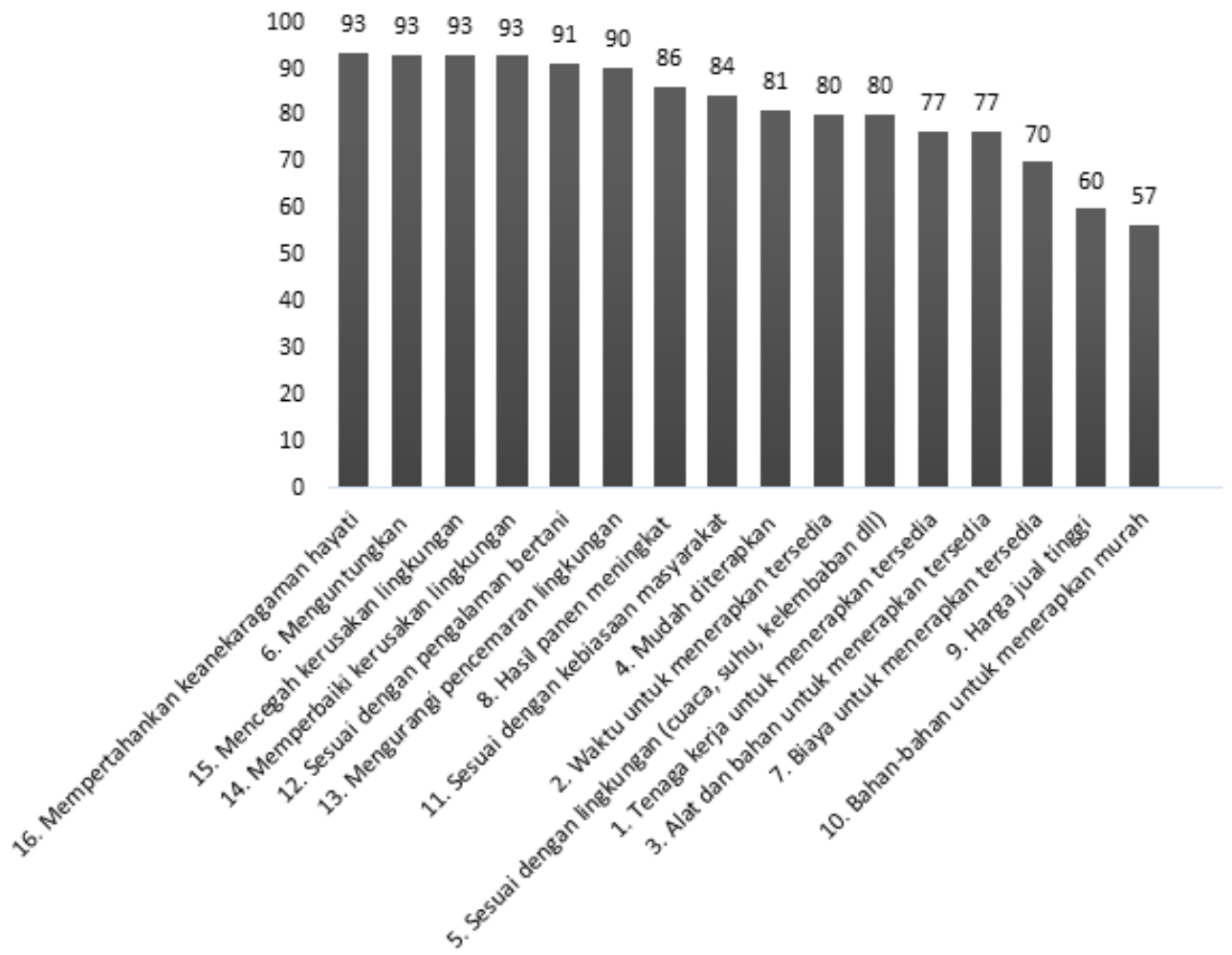

Keterangan: Kelayakan Teknis (1-5),

Kelayakan Ekonomi (6-10),

Kelayakan Sosial (11-12), dan

Kelayakan Lingkungan (13-16)

Gambar 4. Alasan Petani Melaksanakan Materi Penyuluhan yang Diberikan Selama Dua tahun (\% jumlah responden) Terakhir 
melaksanakan. Bahan-bahan untuk menerapkan murah tidak menjadi pertimbangan petani dalam menerapkan materi penyuluhan hortikultura berkelanjutan, hanya 56.67 persen petani yang akan melaksanakan.

\section{Penerimaan Sosial}

Swanson et al. 1997 mengungkapkan bahwa inovasi dapat secara teknis begitu kuat namun dapat pula menimbulkan konflik terhadap norma sosial pada penguna atau dapat menciptakan ketidakseimbangan sosial.Sebagai contoh di Zaire, usaha untuk meningkatkan produksi singkong divatasi oleh kemampuan wanita dalam mengelola peningkatan hasil produksi. Ketika varietas baru diperkenalkan, wanita dalam komunitas target sudah memiliki aktivitas yang sangat padat. Padahal tugas memproses singkong adalah tanggung jawab para wanita namun karena pekerjaan menjadi sangat meningkat maka mereka tidak dapat menangani peningkatan singkong tersebut. Sehingga pada akhirnya mereka kembali menanam varietas lokal yang memiliki hasil rendah. Sebanyak 91.14 persen petani di DIY menyatakan akan melaksanakan materi penyuluhan apabila sesuai dengan pengalaman bertani dan 84.29 persen apabila sesuai dengan kebiasaan masyarakat. Masyarakat DIY sangat menjunjung tinggi nilai-nilai sosial dalam masyarakat dan hingga saat ini budaya gotong-royong masih dilakukan terutama di wilayah-wilayah pedesaan yang mayoritas penduduknya bertani. Pertanian yang dilakukan juga cenderung menggunakan sistem gotong royong dan saling membantu antara petani satu dengan yang lainnya misalnya dalam hal penanaman benih dan pemanenan.

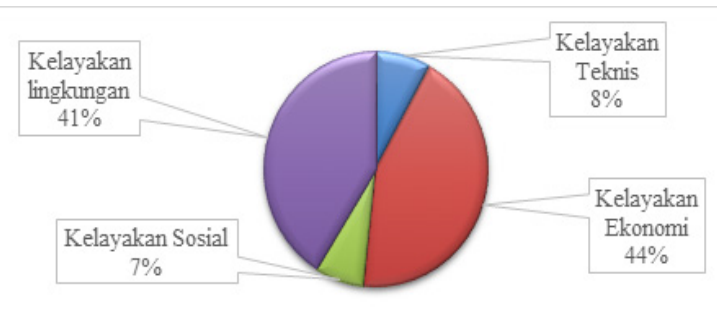

Gambar 5. Kelayakan yang Paling Penting menurut Petani $(\%, N=350)$

Keamanan Lingkungan

Swanson et al. (1997) mengungkapkan bahwa program penyuluhan harus menyadari dampak materi penyuluhan bagi lingkungan. Komersialisasi hasil pertanianmeningkatkan penggunaan pupuk dan bahan kimia pertanian. Bahan kimia tersebut memberikan efek negatif terhadap lingkungan karena mengkontaminasi air tanah dan dapat merusak rantai makanan. Sebagai contoh, burung yang memakan serangga yang terpapar kimia bisa terkontaminasi dan akan mati.

Persepsi atau pengertian petani terhadap kesesuaiankesesuaian keempat lingkup tersebut akan memengaruhi adopsi inovasi. Alasan tertinggi petani menerapkan materi hortikultura berkelanjutan adalah untuk mempertahankan keanekaragaman hayati (93.43 persen). Hal ini sangat wajar karena mayoritas petani adalah petani salak, dan salak merupakan buah local yang merupakan ciri khas masyarakat DIY terutama salak pondoh. Lebih dari 90 persen petani setuju akan melaksanakn materi penyuluhan hortikultura berkelanjutan apabila mencegah kerusakan lingkungan, memperbaiki kerusakan lingkungan dan mengurangi pencemaran lingkungan.

Meskipun petani telah menjawab secara detail aspek kelayakan yang penting menurut mereka dalam melaksanakan materi penyuluhan hortikultura berkelanjutan, responden diminta memilih kembali dari ke-empat kelayakan tersebut secara umum, manakah yang paling penting. Hal ini untuk menunjukkan robustness hasil penelitian. Sebagaimana ditunjukkan pada Gambar 5, penyuluhan di DIY sebaiknya memperkuat konten dalam hal kelayakan ekonomi, aman bagi lingkungan dan berkelanjutan sesuai dengan pernyataan petani bahwa mereka akan menerapkan materi penyuluhan apabila layak secara ekonomi (44 persen) dan aman bagi lingkungan dan berkelanjutan (sesuai kebijakan pemerintah) (41 persen).

\section{Metode Penyuluhan}

Proses atau ketepatan metode penyuluhan adalah keefektifan cara yang dipilih oleh agen perubahan dalam mengubah pengetahuan, keterampilan dan sikap petani antara lain jumlah kunjungan, pertemuan lapang, pertemuan kelompok, demonstrasi, studi banding atau pertukaran petani dan pelatihan petani. Proses atau ketepatan metode terendah berada di Kabupaten Bantul (Gambar 5).

Metode penyuluhan yang ada di DIY sudah 
menggunakan pendekatan partisipatif sebagaimana telah ditampilkan sebelumnya pada tabel 3. Gambar 6 menunjukkan 31 persen responden menyatakan metode penyuluhan yang paling bermanfaat adalah pelatihan (training/sekolah lapang), diikuti dengan uji coba lapangan atau demonstrasi lahan ( 24.57 persen) dan studi banding ke kelompok tani yang lebih baik (23.71 persen).

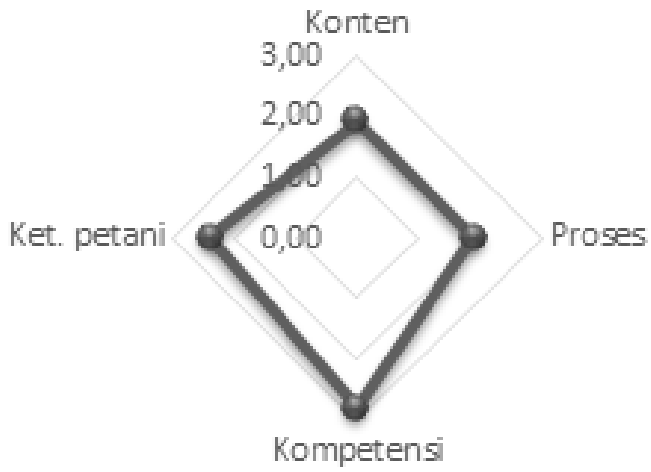

Gambar 5. Distribusi Skor Likert Penyuluhan di Bantul

Pada kenyataannya metode penyuluhan tersebut memiliki nilai terendah pada Gambar 7 yaitu dengan skor likert $=1.77$. Gambar 7 menunjukkan bahwa petani setuju penyuluhan memberikan pengetahuan baru dan bermanfaat bagi usaha pertanian. Metode yang sering dilakukan dalam penyuluhan adalah dengan mengadakan pertemuan kelompok di kelas/ ruangan. Jika dibandingkan antara Gambar 6 dan Gambar 7, maka dapat disimpulkan terdapat beberapa metode penyuluhan yang dilaksanakan dirasakan kurang bermanfaat bagi petani seperti pertemuan kelompok dikelas/ruangan. Pelatihan (training/sekolah lapang) menurut petani memiliki manfaat tinggi namun penyuluhan tipe ini lebih cenderung tergantung pada program pemerintah terutama Kementerian Pertanian.

Swanson et al. (1997) menjelaskan bahwa dalam melaksanakan proses penyuluhan, sejumlah pendekatan yang berbeda dapat digunakan. Pendekatan yang dipilih oleh organisasi penyuluhan bergantung pada pertimbangan kebijakan, termasuk karakteristik petani yang dilayani, misi penyuluhan, dan pertimbangan keuangan atau anggaran yang disediakan pemerintah. Selain itu, jenis pendekatan yang diikuti akan memengaruhi cara suatu program atau inovasi disampaikan di tingkat lapangan. Oleh karena itu, harus diingat bahwa proses pelaksanaan program penyuluhan bergantung pada konteks dan dipengaruhi oleh pendekatan penyuluhan yang dituju oleh organisasi ekstensi nasional.

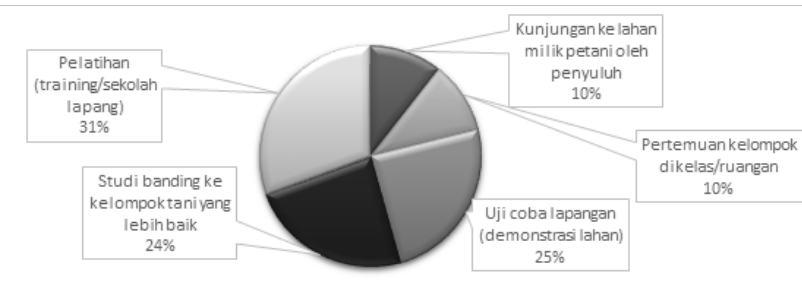

Gambar 6. Metode Penyuluhan yang Paling Bermanfaat $(\%, \mathrm{~N}=350)$

Albrecht et al. (1989) memberikan beberapa tipologi sehubungan dengan kesesuaian materi yang digunakan dalam pendekatan yang berbeda. Mereka berpendapat bahwa semua pendekatan penyuluhan dapat diklasifikasikan sebagai pendekatan teknologi produksi atau pendekatan penyelesaian masalah. Pendekatan teknologi produksi cenderung menekankan target peningkatan produksi. Teknologi yang digunakan dalam pendekatan ini lebih fokus pada penanganan masalah produksi klien penyuluhan yang terkait. Timmer (1982) mengatakan bahwa pendekatan ini diarahkan untuk menghasilkan informasi technoeconomic dan mendukung petani yang lebih besar dan lebih komersial. Para petani kecil tidak menerima penuh manfaat dari pendekatan ini karena situasi yang kurang menguntungkan. Pendekatan yang berfokus pada komoditas dan teknologi adalah contoh dari pendekatan teknologi produksi. Penyuluhan di DIY memang memfokuskan juga pada komoditas, misalnya SL-GAP cabai, pisang, bawang merah dan SLGHP salak pondoh. Fokus juga diarahkan pada teknologi produksi melalui pelatihan budidaya.

Dalam pendekatan pemecahan masalah, klien berpartisipasi dalam mendefinisikan masalah mereka. Meskipun pendekatan ini menggunakan informasi technoeconomic, pertimbangan sosial ekonomi dari klien ditonjolkan sebagai isu penting. Bagi petani kecil, ini memungkinkan untuk pengembangan materi yang lebih tepat. Pelatihan dan kunjungan, penyuluhan pengembangan masyarakat dan pendekatan animasi 


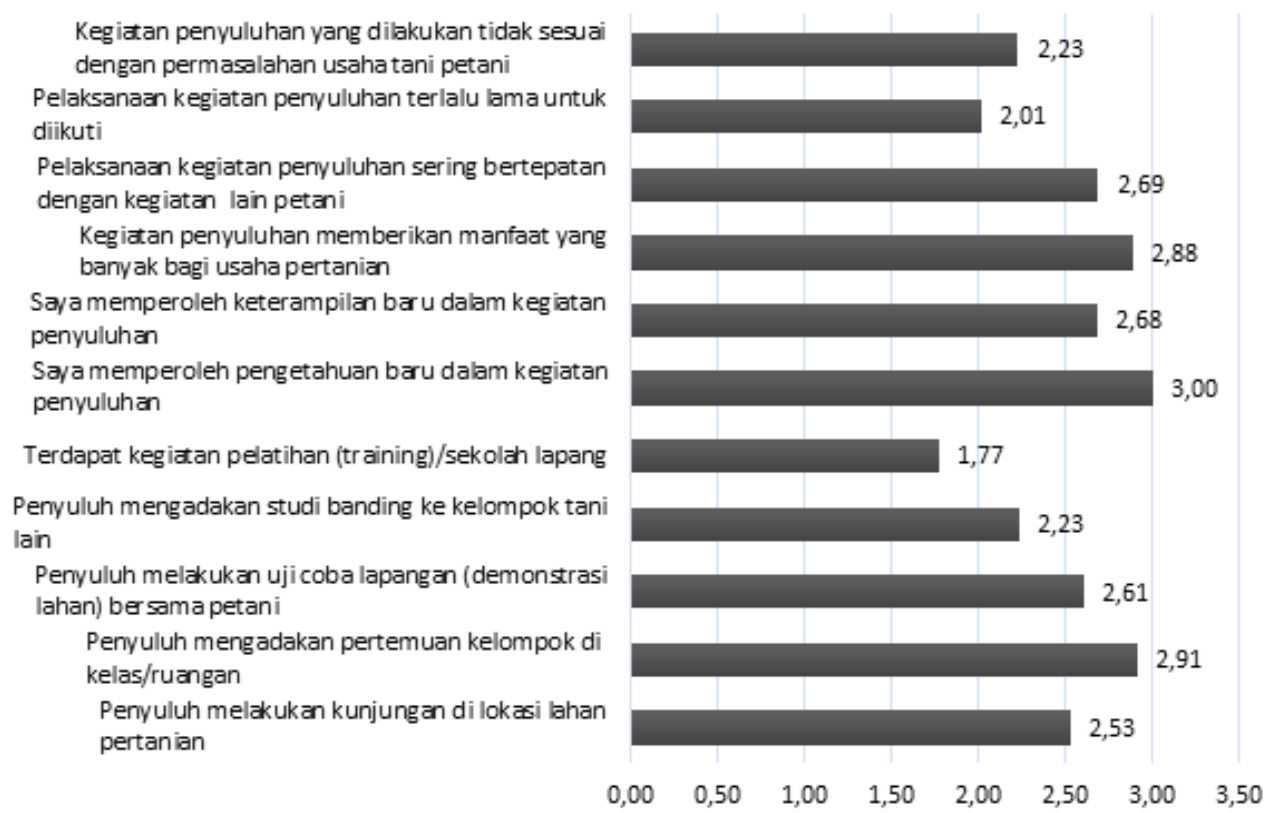

Gambar 7. Skor Likert Metode Penyuluhan (N=350)

pedesaan termasuk dalam kategori ini. Klien penyuluhan adalah kelompok heterogen dari beberapa orang yang dibedakan oleh sumber daya, jenis kelamin, usia, dan etnis.

Teori komunikasi menunjukkan bahwa pengaruh trickle down inovasi pertanian jarang terjadi di antara kelompok-kelompok yang heterogen, dan ketika itu terjadi, maka kecepatan cenderung sangat lambat. Hal ini bisa dijadikan pertimbangan karena hasil survei menunjukkan hampir 50\% responden belum menerima pelatihan, hal ini karena pemerintah mengharapkan bahwa pengurus yang diikutsertakan akan memberikan pengetahuan mereka melalui kelompoknya masingmasing. Sesuai hal tersebut maka penting untuk mengidentifikasi kategori homogen dalam kelompokkelompok dari klien untuk memfasilitasi transfer teknologi yang efektif.

Penargetan kelompok-kelompok ini harus dilakukan dalam kelompok-kelompok yang lebih luas yaitu, zona agroekologi, akses ke sumber daya, wanita, pemuda, etnis, akses informasi, dan usia. Program penyuluhan kemudian harus dikembangkan untuk masing-masing kategori yang ditargetkan (Swanson et al.1984). Seperti halnya program khusus harus dikembangkan untuk wanita yang mengakui pentingnya mereka di sektor pertanian, mengetahui jaringan komunikasi informal mereka, dan menganalisis jadwal pekerjaan pertanianrumah mereka. Apabila kasus program diarahkan pada kelompok etnis, upaya harus ditargetkan untuk faktor sosial budaya yang membedakan kelompok. Bahasa, preferensi makanan, dan keyakinan agama adalah salah satu poin penting yang harus dipertimbangkan. Selain itu, penyuluh dalam mengembangkan programprogram ekstensi harus dipandu oleh prinsip-prinsip pembelajaran dan pengetahuan tentang proses difusi sebagai berikut:

\section{(1) Proses Penyuluhan}

Penyuluh harus memahami prinsip-prinsip dasar pembelajaran dan memahami efektivitas beberapa metode penyuluhan. Penyuluhan melibatkan proses pembelajaran. Belajar difasilitasi oleh penggunaan indra. Semakin banyak indera yang digunakan, semakin pembelajaran akan semakin cepat. Penggunaan prinsip ini akan membantu penyuluh dalam memilih metode yang akan memberikan pengalaman pendidikan untuk klien mereka. Hal ini dapat dicapai melalui pengaturan lingkungan dan penataan situasi sehingga dapat merangsang jenis reaksi yang diinginkan. Belajar juga dikondisikan oleh motivasi dan kemampuan peserta didik sehingga penting untuk menciptakan lingkungan yang kondusif untuk belajar dan peserta didik menjadi lebih bertanggung jawab atas hasil dari pengalaman mereka. Hal ini dapat dicapai melalui pemilihan metode pengajaran dan materi pendukung. Semakin nyata metode yang diterapkan maka mereka akan lebih berpartisipasi, dan pengalaman pendidikan menjadi 
lebih efektif. Jika petani tidak melakukan tugas secara efektif, maka akan jauh lebih efektif dengan metode demonstrasi dibandingkan dengan kuliah atau pertemuan kelompok.

\section{(2) Proses Adopsi}

Swanson et al. (1997) menjelaskan bahwa pertimbangan penting lainnya dalam memilih metode untuk pengiriman materi yang sesuai adalah pemahaman tentang proses adopsi. Lionberger (1960) berpendapat bahwa proses adopsi terdiri atas lima tahap yang berbeda: kesadaran (awareness), ketertarikan (interest), evaluasi (evaluation), percobaan (trial), dan adopsi (adoption). Menurut Lionberger, individu dalam proses melewati setiap tahap didefinisikan periode waktu. Lionberger menunjukkan bahwa pada beberapa tahapan terdapat proses kognitif yang lebih besar sehingga sulit dikenali sebagai yang dapat diukur dari waktu ke waktu.

Meskipun dalam beberapa kasus, langkah-langkah dalam proses adopsi mungkin tidak dikenali, terdapat model yang memberikan panduan yang berguna untuk memilih metode penyuluhan dalam menyampaikan suatu program. Seperti halnya dalam tahap kesadaran, pengetahuan inovasi sangat penting untuk individu. Media massa dan teater populer adalah metode yang disukai karena dapat menjangkau banyak orang pada saat yang bersamaan. Dalam menggunakan media massa, penyuluh harus memperhatikan karakteristik audiens yang ditargetkan. Masyarakat multi ras, kelompok etnis dengan bahasa khusus mungkin memerlukan pemrograman dalam bahasa tersebut.

Pada tahap proses adopsi, keberlanjutan pengetahuan menjadi penting, tetapi membangun sikap positif terhadap inovasi juga menjadi isu yang kritis. Untuk alasan tersebut, metode yang diinginkan harus mencakup informasi yang dapat memperkuat dan membangun sikap sesuai dengan tujuan mereka. Metode ini harus menggunakan indera pendengaran dan penglihatan, baik secara individu maupun kolektif. Pertemuan kelompok, diskusi kelompok, dan forum radio direkomendasikan untuk memperkuat pengetahuan, sedangkan hari lapangan dan kunjungan pertanian akan memungkinkan individu untuk melihat apa yang mereka telah dengar, sehingga memberikan kesempatan untuk membangun sikap yang diinginkan terhadap inovasi.

Evaluasi adalah tahap yang paling penting dalam proses adopsi, karena hasilnya menentukan individu melanjutkan ke tahap percobaan dan adopsi. Di tahap ini, orang harus mencocokkan pengetahuan terhadap fakta-fakta. Petani harus yakin bahwa apa yang mereka dengar dan lihat memang bisa diterapkan. Hasil demonstrasi, pertukaran petani, dan hari lapangan dianjurkan karena memungkinkan individu untuk memperkuat minat mereka dengan melihat bukti nyata. Dalam kelompok metode ini, pertukaran petani merupakan metode penting. Petani yang menjalani pertukaran harus lebih maju dalam proses adopsi dan dalam kelompok referensi yang sama dengan petani mengunjungi. Jenis pengalaman memungkinkan untuk penghapusan keraguan petani. Beberapa pelatihan keterampilan mungkin diperlukan pada tahap ini untuk memfasilitasi perkembangan individu ke tahap uji coba.

Pada tahap uji coba, keterampilan teknis dan manajemen petani harus menjadi wilayah target utama. Kunjungan individu menjadi metode yang paling disukai pada tahap ini, dan kebutuhan individu petani harus dipertimbangkan. Hal ini berarti bahwa petugas penyuluhan harus mengembangkan rencana untuk setiap petani atau kelompok individu petani dengan situasi sejenis.

Penyuluh harus ingat bahwa meskipun petani serupa mengadopsi teknik yang mirip, masalah yang dialami tidak selalu sama. Dalam tahap ini, metode untuk memperkuat ketertarikan petani dengan menggunakan pertukaran petani dan pelatihan keterampilan dapat berguna dalam membantu individu untuk terus mengadopsi.

Setelah petani mulai mengadopsi, penyuluh harus terus mendukung upaya mereka. Program pengakuan dan kompetisi petani dapat digunakan untuk mendorong petani agar terus mengadopsi. Tujuan dan kriteria untuk metode ini harus hati-hati dikembangkan sehingga tidak memberikan efek negatif karena perencanaan dan pelaksanaan yang buruk. Metode yang direkomendasikan dirangkum dalam Gambar 8. Metode yang direkomendasikan untuk tahapan yang berbeda dari adopsi diringkas dalam Gambar 8. Untuk mencapai hasil maksimal dari metode yang 
dipilih pada tahap yang berbeda, petugas penyuluhan harus memahami proses pembelajaran. Seperti halnya dalam pertemuan kelompok petugas penyuluhan dapat menggunakan format kuliah, didukung dengan video, dan diikuti dengan diskusi kelompok.

Metode yang dipilih akan bergantung pada tujuan, sumber daya, hubungan klien, dan keterampilan penyuluh, dan pada ukuran dan tingkat pendidikan kelompok sasaran. Jika penyuluh tidak memiliki keterampilan untuk mengatur dan memfasilitasi pertemuan kelompok, maka mereka berusaha untuk tidak menggunakan. Jika penyuluh tidak memiliki kendaraan, maka mereka mungkin tidak dapat melakukan kunjungan pertanian sesering mungkin seperti yang diinginkan atau dibutuhkan. Sebagai panduan dalam pemilihan metode penyuluhan, van den Ban dan Hawkins (1985) memberikan seperangkat kriteria untuk menilai bahwa metode penyuluhan dipilih dengan baik:

(1) Apakah metode yang dipilih disesuaikan dengan apa yang ingin diubah yaitu mengubah pengetahuan, keterampilan, sikap, atau perilaku?

(2) Apakah kegiatan pendidikan secarajelas ditentukan sehingga dapat diketahui apa yang akan dilihat, di dengar, didiskusikan, dan dilaksanakan petani?
(3) Apakah dalam penyuluhan berbagai metode berbeda terintegrasi sedemikian rupa sehingga saling memperkuat satu sama lain?

(4) Apakah skala waktu yang direncanakan memungkinkan untuk melaksanakan semua kegiatan ini dengan baik?

(5) Ketika memilih kegiatan belajar, apakah penyuluh telah mempertimbangkan kebutuhan, keterampilan, dan sarana kelompok sasaran secara cukup?

Berdasarkan uraian tersebut, maka dapat disimpulkan bahwa metode yang dipilih oleh penyuluhan lebih banyak berada pada tahap membangun awareness dan interest dan mulai bergerak kepada evaluation dan trial. Sedangkan metode penyuluhan dalam tahap adopsi belum banyak dijalankan atau masih sedikit misalnya melalui pemberian sertifikat PRIMA. Metode pembelajaran yang diterapkan oleh penyuluh sebaiknya berdasarkan tahapan adopsi klien untuk mengubah perilaku klien atau pengetahuan, keterampilan dan sikap.

Berdasarkan hasil survei, cara paling efektif adalah dengan pelatihan (training/sekolah lapang), diikuti dengan uji coba lapangan atau demonstrasi lahan dan studi banding ke kelompok tani yang lebih baik dalam

Adoption
$\begin{gathered}\text { Pengakuan program, } \\ \text { kompetisi, menjalankan } \\ \text { praktik dalam sistem } \\ \text { pertanian }\end{gathered}$
$\begin{gathered}\text { Kunjungan individual, } \\ \text { metode pertukaran petani. } \\ \text { Demonstrasi, percobaan di } \\ \text { lahan pertanian }\end{gathered}$
Interest
$\begin{gathered}\text { Hasil demonstrasi, pertukaran } \\ \text { petani, metode demonstrasi } \\ \text { Pertemuan kelompok, diskusi } \\ \text { kelompok, forum radio, hari } \\ \text { lapangan, kunjungan lahan } \\ \text { pertanian }\end{gathered}$

Gambar 8. Rekomendasi Metode Penyuluhan Sesuai Tahap Adopsi (Swanson et al. 1997) 
mencapai tujuan hortikultura berkelanjutan dipadukan dengan kriteria metode penyuluhan van den Ban dan Hawkins (1985). Hal ini sejalan dengan MandirizaMukwirimba et al. (2016) bahwa sekolah lapang di area yang sama dapat dijadikan ajang untuk belajar bersama tentang berbagai macam penyakit tanaman dengan bantuan penyuluh, institusi peneliti dan berbagai organisasi petani.

Begum et al. (2016) juga berpendapat bahwa sekolah lapang dan pelatihan dapat menolong petani untuk belajar sambil melakukan (learning by doing) untuk meningkatkan kemampuan analitis dan pengambilan keputusan untuk teknologi pertanian yang lebih baik.

\section{Kompetensi Penyuluh}

Secara umum kompetensi penyuluh di Yogyakarta sudah baik. Kompetensi ini meliputi penguasaan tentang pengetahuan, keterampilan, dan perilaku yang harus dimiliki, dihayati dan dikuasai sesuai dengan tugas pokok dan fungsinya sebagai tenaga profesional dalam melakukan kegiatan proses pembelajaran. Kompetensi tersebut meliputi penguasaan pengetahuan mengenai hortikultura berkelanjutan, keterampilan dalam berkomunikasi, menyiapkan materi, menerapkan media dan metode serta dalam hal memberikan rekomendasi terhadap petani. Kompetensi penyuluh di seluruh kabupaten di
DIY berada dalam kategori tinggi.

Petani setuju bahwa penyuluh sangat memperhatikan kelestarian lingkungan namun penyuluh masih memperbolehkan petani menggunakan bahan kimia dalam memberantas hama atau gulma (Gambar 9). Kendala-kendala yang dihadapi seperti sulitnya memperoleh pemberantas hama atau gulma nabati ataupun organik mungkin menjadi latar belakang mengapa penyuluh masih memperbolehkan hal tersebut. Sebagian besar petani jarang mengetahui cara pembuatan pemberantas hama atau gulma nabati ataupun organik karena belum pernah menerima pelatihan mengenai hal tersebut.

\section{Keterlibatan Petani}

Keterlibatan atau partisipasi petani adalah tingkat keikutsertaan petani khususnya pada komoditas hortikultura dalam kegiatan rutin kelompok. Keterlibatan petani di DIY memiliki skor 1.97 atau dalam kategori sedang, merupakan skor paling rendah dari komponen penyuluhan yang ada. Penyebabnya adalah petani masih mengandalkan program penyuluhan sehingga memiliki skor rendah. Keterlibatan petani terendah berada di Kabupaten Sleman (Gambar 10).

Dalam survey di lapangan, petani sangat jarang bertemu

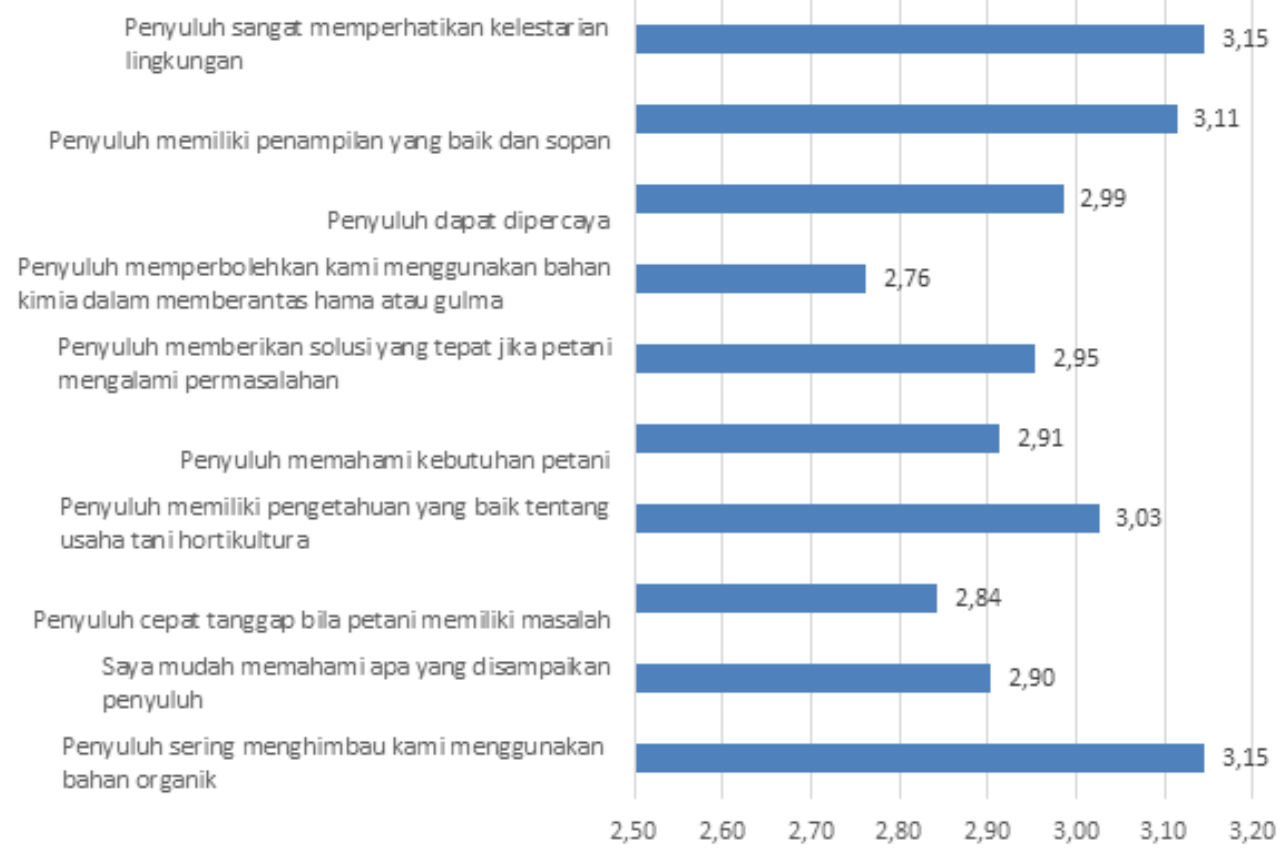

Gambar 9. Kompetensi Penyuluh 
penyuluh jika tidak ada program dari pemerintah. Terbatasnya jumlah penyuluh juga menjadi faktor penyebab rendahnya frekuensi pertemuan petani dan penyuluh. Hanya beberapa petani yang berinisiatif menemui penyuluh dapat lebih sering bertemu dengan penyuluh.

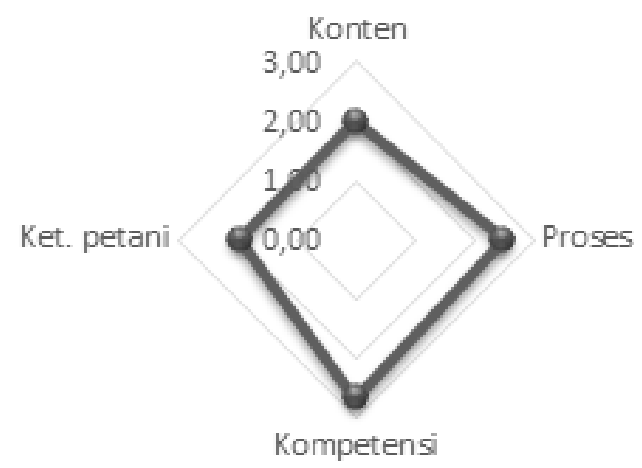

Gambar 10. Distribusi Skor Likert Penyuluhan di Sleman

Partisipasi sepadan dengan arti peran serta, ikut serta, keterlibatan, atau proses belajar bersama saling memahami, menganalisis, merencanakan dan melakukan tindakan oleh sejumlah anggota masyarakat. Asngari (2001) menyatakan bahwa, penggalangan partisipasi itu dilandasi adanya pengertian bersama dan adanya pengertian tersebut adalah karena di antara orang-orang itu saling berkomunikasi dan berinteraksi sesamanya.

Dalam menggalang peran serta semua pihak itu diperlukan: (1) terciptanya suasana yang bebas atau demokratis, dan (2) terbinanya kebersamaan. Selanjutnya Slamet (2003) menyatakan bahwa, partisipasi masyarakat dalam pembangunan adalah sebagai ikut sertanya masyarakat dalam pembangunan, ikut dalam kegiatan-kegiatan pembangunan, dan ikut serta memanfaatkan dan menikmati hasil-hasil pembangunan.

Gaventa dan Valderama (1999) mengungkapkan ada tiga tradisi konsep partisipasi terutama bila dikaitkan dengan pembangunan masyarakat yang demokratis yaitu:

(1) Partisipasi Politik (political participation) lebih berorientasi pada"memengaruhi" dan "mendudukan wakil-wakil rakyat" dalam lembaga pemerintahan ketimbang partisipasi aktif dalam proses-proses kepemerintahan itu sendiri.
(2) Partisipasi Sosial (social participation) partisipasi ditempatkan sebagai keterlibatan masyarakat terutama yang dipandang sebagai beneficiary atau pihak di luar proses pembangunan dalam konsultasi atau pengambilan keputusan dalam semua tahapan siklus proyek pembangunan dari evaluasi kebutuhan sampai penilaian, implementasi, pemantauan dan evaluasi. Partisipasi sosial sebenarnya dilakukan untuk memperkuat proses pembelajaran dan mobilisasi sosial. Dengan kata lain, tujuan utama dari proses partisipasi sosial sebenarnya bukanlah pada kebijakan publik itu sendiri tetapi keterlibatan komunitas dalam dunia kebijakan publik lebih diarahkan sebagai wahana pembelajaran dan mobilisasi sosial.

(3) Partisipasi Warga (citizen participation/citizenship) menekankan pada partisipasi langsung warga dalam pengambilan keputusan pada lembaga dan proses kepemerintahan. Partisipasi warga telah mengalihkan konsep partisipasi "dari sekedar kepedulian terhadap 'penerima derma' atau 'kaum tersisih' menuju ke suatu kepedulian dengan berbagai bentuk keikutsertaan warga dalam pembuatan kebijakan dan pengambilan keputusan di berbagai gelanggang kunci yang memengaruhi kehidupan mereka". Maka berbeda dengan partisipasi sosial, partisipasi warga memang lebih berorientasi pada agenda penentuan kebijakan publik oleh warga ketimbang menjadikan arena kebijakan publik sebagai wahana pembelajaran.

Jika dilihat berdasarkan tipe partisipasi Gaventa dan Valderama(2009), partisipasi petani hortikultura di DIY lebih cenderung merupakan partisipasi sosial karena keterlibatan komunitas petani dalam dunia kebijakan publik lebih diarahkan sebagai wahana pembelajaran dan mobilisasi sosial. Partisipasi masyarakat terbagi menjadi empat tahap menurut Uphoff et al. (1979), yaitu:

(1) Tahap perencanaan, ditandai dengan keterlibatan masyarakat dalam kegiatan-kegiatan yang merencanakan program pemberdayaan yang akan dilaksanakan di desa, serta menyusun rencana kerjanya.

(2) Tahap pelaksanaan, yang merupakan tahap terpenting dalam pemberdayaan, sebab inti dari pemberdayaan adalah pelaksanaannya. Wujud nyata partisipasi pada tahap ini dapat digolongkan menjadi tiga, yaitu partisipasi dalam bentuk 
sumbangan pemikiran, bentuk sumbangan materi, dan bentuk keterlibatan sebagai anggota proyek.

(3) Tahap menikmati hasil, yang dapat dijadikan indikator keberhasilan partisipasi masyarakat pada tahap perencanaan dan pelaksanaan program. Selain itu, dengan melihat posisi masyarakat sebagai subjek pemberdayaan, maka semakin besar manfaat program dirasakan, berarti program tersebut berhasil mengenai sasaran.

(4) Tahap evaluasi, dianggap penting sebab partisipasi masyarakat pada tahap ini dianggap sebagai umpan balik yang dapat memberi masukan demi perbaikan pelaksanaan program selanjutnya.

Pretty (1995a) mengungkapkan bahwa tipe partisipasi yang digunakan suatu institusi dalam penyuluhan

\section{Tabel 4. Tipe Partisipasi: Cara Partisipasi Seseorang dalam Pengembangan Program dan Proyek}

Tipe Partisipasi

(1) Partisipasi

Manipulatif

(2) Partisipasi Pasif

(3) Partisipasi

Konsultasi

(4) Partisipasi

Insentif Materi

\section{Karakteristik Tipe Partisipasi}

Partisipasi ini tidak nyata, ada perwakilan dan tercantum sebagai pengurus atau penanggung jawab tapi sesungguhnya mereka tidak dipilih dan tidak memiliki kekuatan.

Orang berpartisipasi dengan diberitahu apa yang telah diputuskan atau sudah terjadi. Pengumuman atau pemberitahuan dilakukan sepihak oleh administrasi atau manajemen proyek tanpa mendengarkan tanggapan masyarakat. Informasi yang dibagikan hanya dimiliki profesional eksternal.

Orang berpartisipasi dengan berkonsultasi atau menjawab pertanyaan. Agen eksternal melakukan pengumpulan informasi dan mendefinisikan masalah serta analisis pengendaliannya. Proses konsultatif tidak memengaruhi pengambilan keputusan, dan para profesional tidak berkewajiban untuk mempertimbangkan pandangan masyarakat.

Orang berpartisipasi dengan menyumbangkan sumber daya, seperti tenaga kerja, dan dikembalikan dalam bentuk makanan, uang atau insentif material lainnya. Petani menyediakan lahan dan tenaga kerja, tetapi tidak terlibat dalam eksperimen maupun proses pembelajaran. Kebanyakan hal ini sudah disebut partisipasi padahal ketika insentif berakhir, maka penggunaan teknologi dan praktik yang dilaksanakan juga berakhir karena mereka merasa tidak memiliki peran untuk meneruskan.

(5) Partisipasi Fungsional

Partisipasi dilihat oleh lembaga eksternal sebagai sarana untuk mencapai tujuan proyek dan mengurangi biaya-biaya. Orang dapat berpartisipasi dengan membentuk kelompok untuk mencapai tujuan yang telah ditetapkan terkait dengan proyek. Keterlibatan seperti ini mungkin interaktif dan melibatkan pengambilan keputusan bersama, tapi cenderung muncul hanya setelah keputusan besar telah dibuat oleh agen eksternal. Masyarakat setempat hanya ditujukan untuk mencapai tujuan eksternal.

(6) Partisipasi Interaktif Orang berpartisipasi dalam analisis bersama, pengembangan rencana aksi dan pembentukan atau penguatan institusi lokal. Partisipasi dipandang sebagai hak, bukan hanya sarana untuk mencapai tujuan proyek. Proses ini melibatkan metodologi interdisipliner yang mencari berbagai perspektif dan menggunaan proses pembelajaran sistemik dan terstruktur. Kelompok mengambil kontrol atas keputusan lokal dan menentukan penggunaan sumber daya yang tersedia, sehingga mereka merasa memiliki andil dalam mempertahankan struktur atau praktik.

(7) Mobilisasi Pribadi Orang berpartisipasi dengan mengambil inisiatif independen dari lembaga eksternal untuk mengubah sistem. Mereka mengembangkan hubungan dengan lembaga eksternal untuk saran terkait sumber daya dan teknis yang mereka butuhkan, tetapi mereka tetap memiliki kontrol atas penggunaan sumber daya. Mobilisasi diri dapat menyebar jika pemerintah dan LSM memberikan kerangka dukungan. Mobilisasi yang dinisiasi oleh pribadi tersebut mungkin dapat atau tidak dapat menantang distribusi kekuasaan dan kesejahteraan.

Sumber: Pretty (1995a), Hart (1992) 
akan menentukan efektivitas dari penyuluhan tersebut. Menurut Pretty (1995a), cara organisasi menafsirkan danmenggunakan istilah partisipasidapatdikategorikan dalam tujuh jenis partisipasi dari partisipasi pasif hingga manipulatif yaitu ketika orang-orang diberitahu apa yang terjadi, mereka akan bertindak sesuai peran, memobilisasi diri mereka sendiri, dan mereka melakukan inisiatif secara independen dengan institusi eksternal (Tabel 4).

Tipe-tipe ini menunjukkan bahwa kita tidak dapat mendefinisikan kata partisipasi tanpa klarifikasi yang jelas. Banyak sekali yang mengartikan partisipasi tidak sesuai dengan definisi sesungguhnya karena orangorang yang menjadi sasaran penyuluhan hanya bersifat pasif. Rahnema (1992) mengungkapkan bahwa tipe partisipasi manipulatif, partisipasi pasif, partisipasi konsultasi, partisipasi insentif materi tidak dapat memiliki efek postif dalam kehidupan masyarakat dan Hart (1992) menyebutnya sebagai non-partisipasi.

Gambar 11 menunjukkan bahwa tipe partisipasi tertinggi adalah tipe partisipasi pasif (saya sering hadir dalam pertemuan kelompok) dan tipe partisipasi terendah adalah pada tipe partisipasi mobilisasi pribadi (saya mencari solusi dengan pihak lain selain penyuluh PNS apabila ada masalah kelompok).
Budaya mengajak anggota lain untuk berpartisipasi dalam pertemuan kelompok memiliki nilai tertinggi setelah kehadiran. Ini dapat memudahkan penyuluh dalam menyampaikan suatu program. Partisipasi dalam bentuk kehadiran dilakukan karena berbagai alasan, antara lain untuk menambah informasi dan pengetahuan, memecahkan masalah, bertukar pengalaman, dan menjaga kerukunan. Penelitianpenelitian terdahulu seperti Indraningsih (2011) dan Mulyadi et al. (2007) tidak memasukkan konsep partisipasi padahal penelitian Tey et al. (2014) serta

Kabir dan Rainis (2014) disebutkan bahwa petani yang terlibat dalam kelembagaan cenderung menerapkan praktik pertanian berkelanjutan. Hal tersebut diukur dari keanggotaan petani dalam lembaga, partisipasi dalam program-program pemerintah maupun swasta yang terkait lingkungan dan partisipasi kelembagaan. Akan tetapi penelitian Tey et al. (2014) serta Kabir dan Rainis (2014) mengenai partisipasi dalam adopsi pertanian berkelanjutan yang digunakan juga masih berupa keterlibatan.

Thanh dan Yapwattanaphun (2015) memasukkan partisipasi sebagai karakteristik sosial ekonomi dan menggunakan konsep partisipasi dalam penyuluhan sebagai faktor yang memengaruhi adopsi inovasi sebagaimana pendapat Kassie et al. (2013), Okuthe

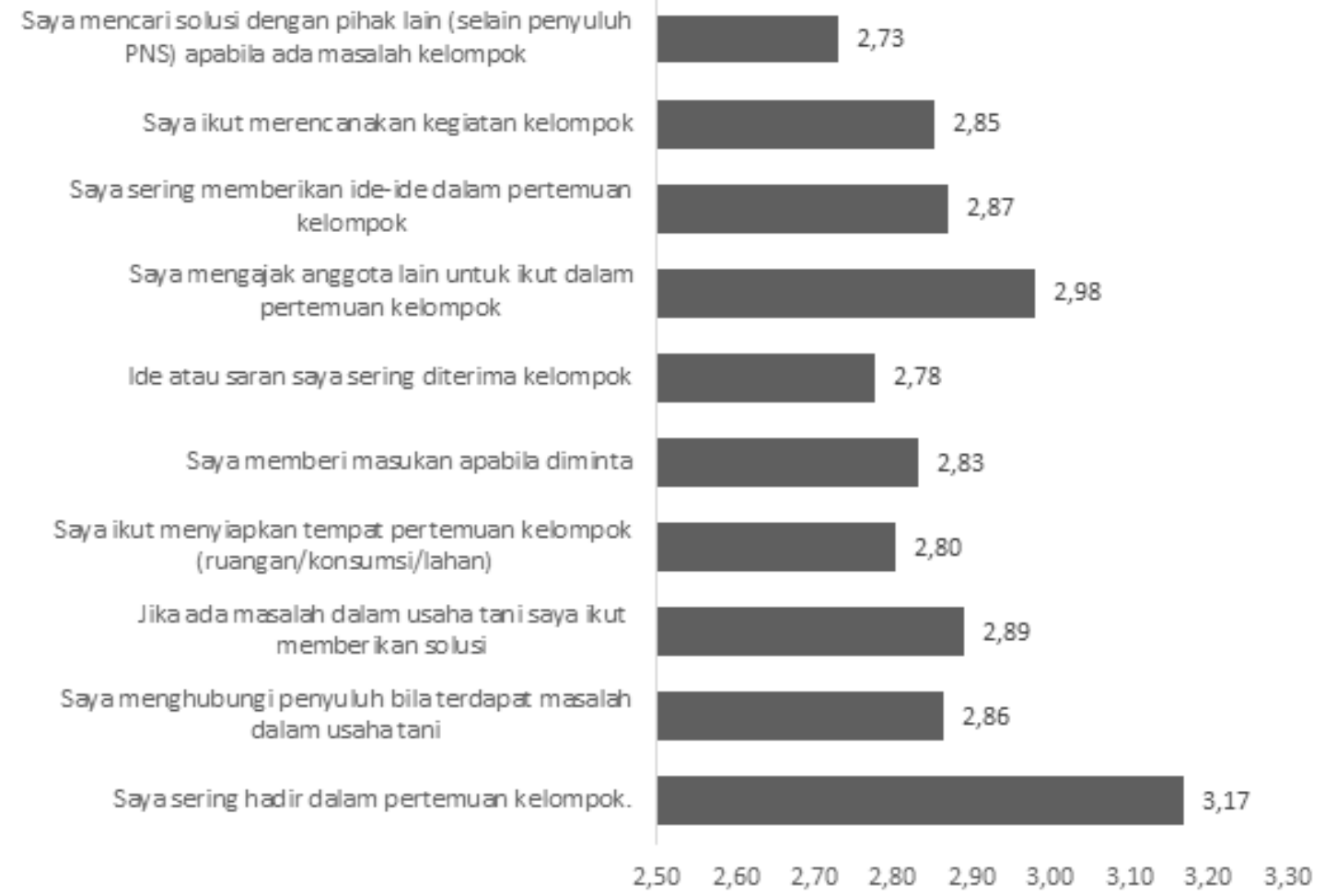

Gambar 11. Partisipasi Petani $(\mathrm{N}=350)$ 
(2014) dan Timprasert et al. (2014). Thanh dan Yapwattanaphun (2015) mengukur partisipasi hanya sebagai tingkat kehadiran dalam kursus atau pelatihan maupun demonstrasi saja dan merujuk pada pendapat Gecho dan Punjabi (2011) serta Zegeye and Haileye (2001) bahwa kehadiran dalam pelatihan berkontribusi positif pada adopsi praktik pertanian berkelanjutan. Hal ini tentu bertolak belakang dengan pendapat Pretty (1995a) terkait tipe partisipasi.

Upaya meningkatkan partisipasi dapat dilakukan dengan meningkatkan kontak penyuluh dengan petani. Hal ini sejalan dengan van den Ban dan Hawkins (1999) yang mengartikan penyuluhan sebagai keterlibatan seseorang untuk melakukan komunikasi informasi secara sadar dengan tujuan membantu sesamanya memberikan pendapat sehingga bisa membuat keputusan yang benar. Okonya et al. (2016) mengungkapkan bahwa kontak dengan penyuluh diperlukan untuk meningkatkan pengetahuan petani misalnya dalam menerapkan Integrated Pest Management (IPM). Kontak dengan penyuluh terbukti dapat meningkatkan praktek hortikultura berkelanjutan seperti meningkatkan varietas tanaman (Ahmed 2016). Sebagian besar petani melakukan kontak dengan penyuluh melalui pertemuan rutin yang diadakan paling tidak sebulan sekali ataupun langsung menghubungi penyuluh melalui telepon genggam.

Upaya lain untuk meningkatkan partisipasi adalah dengan mempertimbangkan faktor-faktor yang memengaruhinya. Menurut Hermawan et al. (2017) faktor-faktor yang dapat memengaruhi partisipasi adalah karakteristik petani (tingkat pendidikan formal, tingkat Pendidikan non-formal, motivasi berkelompok, skala usaha, tingkat kekosmopolitan) dan faktor dukungan kelompok (tujuan, fungsi, manfaat, kepemimpinan, fasilitas, dan kekompakan kelompok).

\section{Kesimpulan}

Efektivitas implementasi penyuluhan di DIY berada dalam kategori tinggi dengan materi penyuluhan, metode penyuluhan dan kompetensi penyuluh pada kategori tinggi, sedangkan keterlibatan petani pada kategori sedang. Materi penyuluhan perlu diperkuat dalam hal penggunaan bahan organik sebagai mulsa dan juga dalam hal pemasaran. Materi penyuluhan tersebut harus mempertimbangkan aspek kelayakan lingkungan dan ekonomi yang menjadi faktor utama petani dalam menerapkan materi penyuluhan.

Metode penyuluhan yang dipilih harus mempertimbangkan tahapan adopsi inovasi. Sebagian petani telah mencapai tahap adopsi sehingga diperlukan metode penyuluhan yang memberikan pengakuan, atas adopsi yang dilakukan petani. Petani lebih merasakan manfaat pada pelatihan (training) dan sekolah lapang dibandingkan metode lain sehingga kedepannya penyuluhan lebih diarahkan melalui kegiatan tersebut.

Kompetensi penyuluh di Yogyakarta sudah sangat baik dan masih dapat ditingkatkan. Meskipun demikian penyuluh harus lebih ditingkatkan dalam kecepatan memberikan respon atau tanggapan terhadap permasalahan yang dihadapi petani. Keterlibatan petani dengan skor paling rendah diantara indikator implementasi penyuluhan.

Penyuluh harus membuat strategi agar petani lebih meningkatkan partisipasinya dari partisipasi pasif menjadi partisipasi mobilisasi pribadi. Implementasi penyuluhan dapat diperkuat dengan mempertimbangkan kebutuhan petani terlebih dahulu di masing-masing desa sehingga keterlibatan petani akan semakin meningkat dengan sendirinya. Identifikasi kebutuhan tersebut harus melibatkan petani, dan program penyuluhan yang dilaksanakan juga harus berdasarkan kebutuhan petani tersebut dan dilrumuskan bersama dengan petani. Perlu dilakukan penelitian lebih lanjut mengenai motivasi petani dalam melaksanakan hortikultura berkelanjutan sehingga dapat diperoleh strategi yang lebih efektif dan efisien.

\section{Referensi}

Abdollahzadeh G, Sharifzadeh MS, Damalas CA. 2015. "Perceptions of the beneficial and harmful effects of pesticides among Iranian rice farmers influence the adoption of biological control." Crop Protection. 75: 124-131.

Ahmed MH. 2016. "Climate change adaptation strategies of maize producers of the Central Rift Valley of Ethiopia." Journal of Agriculture and Rural Development in the Tropics and Subtropics. 117 (1):175-186.

Albrecht H, Bergman H, Diederich G, Grober E, Hofman V, Keller P, Payr G, Sülzer R. 1989. 
Agricultural extension: Basic concepts and methods (Vol. 1). Eschborn: BMZ/GTZ/CTA.

Asngari PS. 2001. Peranan Agen Pembaruan/ Penyuluh dalam Usaha Memberdayakan (Empowerment) Sumber daya Manusia Pengelola Agribisnis, $\square$ Orasi Ilmiah Guru Besar Tetap Ilmu Sosial Ekonomi, $\square$ Fakultas Peternakan, $\square$ IPB. (dibacakan pada Tanggal, 15 September 2001).

Begum MEA, Nastis SA, Papanagiotou E, 2016.

"Determinants of technical efficiency of freshwater prawn farming in southwestern Bangladesh." Journal of Agriculture and Rural Development in the Tropics and Subtropics. 117(1):99-112.

BPS DIY. 2014. Daerah Istimewa Yogyakarta Dalam Angka. BPS Provinsi D.I. Yogyakarta.

FAO. 1991. International directory of agricultural extension organizations. Rome: FAO.

Gaventa J, Valderrama CB. 2009. Strengthening Participation in Local Governance. Workshop. Institute of Development Studies. June: 21-24.

Gecho Y, Punjabi N. 2011. "Determinants of Adoption of Improved Maize Technology in Damot Gale, Wolaita, Ethiopia. Raj." J. Extn. Edu. 19: 1-9.

Hart RA. 1992. Children's Participation: From Tokenism to Citizenship. UNICEF Innocenti Essays No. 4. Florence: UNICEF.

Hayami Y, Ruttan V. 1985. Agricultural Development: an international perspective. Baltimore, MD: Johns Hopkins University Press.

Hermawan A, Amanah S, Fatchiya A. 2017. "Partisipasi pembudidaya ikan dalam kelompok usaha akuakultur di Kabupaten Tasikmalaya, Jawa Barat." Jurnal Penyuluhan. 13:1-13.

Indraningsih K S. 2011. "Pengaruh Penyuluhan Terhadap Keputusan Petani dalam Adopsi Inovasi Teknologi Usahatani Terpadu." Jurnal Agro Ekonomi. 29(1):1-24.

Jamal K, Kamarulzaman NH, Abdullah AM, Ismail MM, Hashim M. 2014. "Adoption of fragrant rice farming: The case of paddy farmers in the East Coast Malaysia." UMK Procedia. 1: 8-17.

Kabir MH, Rainis R. 2014. "Adoption and intensity of Integrated Pest Management (IPM) vegetable farming in Bangladesh: an approach to sustainable agricultural development." Environ Dev Sustain. DOI 10.1007/s10668-014-9613-y.

Kassie M, Jaleta M, Shifera B, Mmbando F, Mekuria M. 2013. "Adoption of Interrelated Sustainable Agricultural Practices in Smallholder Systems:
Evidence from Rural Tanzania." Technological Forecasting and Social Change. 80: 525-540.

Lionberger HF. 1960. Adoption of New Ideas and Practices. Iowa: The Iowa State University press.

Lippitt T, Watson J, Westley B. 1958. The Dynamics of Planned Change. New York.

Mandiriza-Mukwirimba G. Kritzinger Q. Aveling T. 2016. "A survey of brassica vegetable smallholder farmers in the Gauteng and Limpopo provinces of South Africa." Journal of Agriculture and Rural Development in the Tropics and Subtropics. 117(1): 35-44.

Mulyadi, Sugihen BG, Asngari PS, Susanto D. 2007. "Proses Adopsi Inovasi Pertanian Suku Pedalaman Arfak Di Kabupaten Manokwari - Papua Barat." Jurnal Penyuluhan. 3(2):110-118

Okonya JS, Kroschel J. 2016. "Farmers' knowledge and perceptions of potato pests and their management in Uganda." Journal of Agriculture and Rural Development in the Tropics and Subtropics. 117 (1):87-97.

Okuthe IK. 2014. "The Influence of Institutional Factors on the Adoption of Integrated Natural Resource Management Technologies by Small Scale Farmers in South Western Kenya." Asian Journal of Agricultural Sciences. 6: 16-32.

Pretty JN. 1995a. Participatory Learning for Sustainable Agriculture. World Development. 23(8): 12471263.

. 1995b. Regenerating Agriculture. London (UK): Earthscan.

Rahnema M. 1992. Participation in W. Sachs (Ed.) The Development Dictionary. London: Zed Books Ltd. 116-131.

Slamet M. 2003. Paradigma Baru Penyuluhan Pertanian di Era Otonomi Daerah di dalam MembentukPolaPerilakuManusiaPembangunan. Penyunting: Ida Yustina dan Adjat Sudradjat. Bogor: IPB Press.

Suryani A, Fatchiya A, Susanto D. 2017. Keberlanjutan Penerapan Teknologi Pengelolaan Pekarangan oleh Wanita Tani di Kabupaten Kuningan.” Jurnal Penyuluhan. 13(1): 50-63.

Swanson BE, Roling N, Jiggins J. 1984. Extension Strategies for Technology Utilization. In B. E. Swanson (Ed.), Agricultural extension: A reference manual. Rome: FAO.

Tey YS, Li E, Bruwer J, Abdullah AM, Brindal M, Radam A, Ismail MM, Darham S. 2014. "The 
Relative Importance of Factors Influencing the Adoption of Sustainable Agricultural Practices: A Factor Approach for Malaysian Vegetable Farmers." Sustain Sci. 9:17-29.

Timmer WJ. 1982. The Human Side of Agriculture:

Theory and Practice of Agricultural Extension. New York: Vantage Press.

Timprasert S, Datta A, Ranamukhaarachchi S. 2014. "Factors Determining Adoption of Integrated Pest Management by Vegetable Growers in Nakhon Ratchasima Province, Thailand." Crop Protection. 62: 32-39.

Thanh NV, Yapwattanaphun C. 2015. "Banana Farmers' Adoption of Sustainable Agriculture Practices in the Vietnam Uplands: the Case of Quang Tri Province.” Agriculture and Agricultural Science Procedia. 5:67-74.

Uphoff NT, John MC, Goldsmith AA. 1979. Feasibility and Application of Rural Development Participation: A State of the Art Paper. Ithaca (USA): Cornell University

van den Ban AW, Hawkins HS. 1985. Agricultural Extension. New York: Longman Scientific and Technical.

Zegeye T, Haileye A. 2001. Adoption of Improved Maize Technologies and Inorganic Fertilizer in Northwestern Ethiopia. Ethiopian Agricultural Research Organization (EARO) and International Maize and Wheat Improvement Center CIMMYT. 